\title{
Review Article \\ Sustaining Biodiesel Production via Value-Added Applications of Glycerol
}

\author{
Omotola Babajide ${ }^{1,2}$ \\ ${ }^{1}$ Environmental and Nano Sciences Group, Chemistry Department, University of the Western Cape, Private Bag X17, \\ Bellville 7535, South Africa \\ ${ }^{2}$ School of Sciences, Obafemi Awolowo University, Adeyemi College of Education, PMB 520 Ondo State, Nigeria
}

Correspondence should be addressed to Omotola Babajide; omotola.babajide@gmail.com

Received 15 April 2013; Accepted 9 July 2013

Academic Editor: Onder Ozgener

Copyright (C) 2013 Omotola Babajide. This is an open access article distributed under the Creative Commons Attribution License, which permits unrestricted use, distribution, and reproduction in any medium, provided the original work is properly cited.

\begin{abstract}
The production of biofuels worldwide has been significant lately due to the shift from obtaining energy from nonrenewable energy (fossil fuels) to renewable sources (biofuels). This energy shift arose as a result of the disturbing crude petroleum price fluctuations, uncertainties about fossil fuel reserves, and greenhouse gas (GHG) concerns. With the production of biofuels increasing considerably and the current global biodiesel production from different feedstock, reaching about 6 billion liters per year, biodiesel production costs have been highly dependent on feedstock prices, ranging from 70 to 25 ; of total production costs, and in comparison with the conventional diesel fuel, the biodiesel is currently noncompetitive. An efficient production process is, therefore, crucial to lowering biodiesel production costs. The question of sustainability, however, arises, taking into account the African diverse conditions and how vital concerns need to be addressed. The major concern about biodiesel production costs can be reduced by finding value-added applications for its glycerol byproduct. This paper, thus, provides an overview of current research trends that could overcome the major hurdles towards profitable commercialization of biodiesel and also proposes areas of opportunity probable to capitalize the surplus glycerol obtained, for numerous applications.
\end{abstract}

\section{Introduction}

Energy plays a vital role in the economic development and social/national security of any nation, as access to secure, sustainable, and affordable energy is a prerequisite for sustainable development [1]. Current patterns of energy supply and energy use are unsustainable because of environmental issues such as global warming strongly associated with increased energy consumption. Energy sufficiency and security is a key factor in development since it provides essential inputs for socioeconomic development that provide vital services which improve the quality of life at regional, national, and subnational levels $[2,3]$. Several countries on the African continent continue to face great challenges of energy security and the negative effects of climate change. The strong tie between energy, Millennium Development Goals (MDGs), and widespread poverty makes it important to tackle the challenges and prospects for energy services provision in the continent [4]. The inability of many African countries to provide good and adequate energy services has been a major constraint to their development. The continent remains friable with widespread poverty that is due to several factors [2], and about half of the African population still lives in absolute poverty with approximately $70 \%$ depending on traditional biomass as their only source of fuel [5]. Renewable energy technologies (RETs) in general and biofuel specifically offer developing countries some prospect of a self-reliant energy supply at the national and local levels with potential economic, ecological, social, and security benefits [6].

\section{Biofuels Development in Africa}

Africa is an unexplored and unexploited resource for biofuels development. Although the majority of the African countries rely on biomass (mainly wood from forests) as a main energy resource, it is inefficiently and unsustainably used, with detrimental effects on the environment and the well-being of its inhabitants. These detrimental effects are triggered by the 
main anthropogenic greenhouse gas (GHG), carbon dioxide $\left(\mathrm{CO}_{2}\right)$, because it is closely associated to the prevalent use of fossil energy. $\mathrm{CO}_{2}$ emissions from the combustion of fossil fuels such as coal, petroleum, and natural gas are the most important sources of anthropogenic GHG emissions all over the industrialized countries. Securing the supply of fossil fuel has besieged and caused environmental destruction of the planet Earth. Energy from renewable sources offers a solution proposed to combat the depletion of the world's nonrenewable energy sources, and this kind of energy is beneficial for the natural environment, but the cost of energy production from renewable sources is very high and exceeds the price of conventional fuels [7-9]. According to a report from the African Development Bank in 2006 [10], about $39 \%$ of the total energy consumed in the Subsaharan Africa is imported against a world average of $19 \%$ confirming the heavy dependence on imported fuel. In Africa, as reported by Amigun et al. [4], the biodiesel industry is marginal, whereas the production potential is enormous. A number of small-scale plants had sprung up in South Africa, while some large-scale commercial plants in Europe supply and offer consultancy operations which in turn play a significant role in enabling the African corporate partners to achieve the laid down objectives and programs. Since 2005, several African nations have used the private sector investment strategies and now benefit from the establishment of large-scale J. curcas plantations [11]. The most promising cultivation regions are based in Mozambique, Ghana, Malawi, Tanzania, and Zimbabwe [12] with Mozambique widely seen as possessing the largest potential for $J$. curcas production. The International Energy Agency estimated that Mozambique could produce nearly 3 million barrels of oil a day of liquid biofuels from nonfood crop resources such as J. curcas [13]. In Mozambique, three significant projects were announced during 2006-2007. Canadian-based Energem Resources invested \$5.5 million (4 million) on its first small plantation with near-future commitments to cultivate 60,000 hectares. The South Africabased Duelco renewable energy established Mozambique partnerships around a 60,000-hectare plantation, and ESVBio Africa currently manages an 11,000-hectare plantation with plans for 100,000 hectares [14]. Ghana planned a 12,000hectare project with the South Africa-based BD-1 Group with interest in J. curcas production from Petrobras, and other foreign-based companies. According to a current report, Ghana ranks among the "top 5" list of the developing countries likely to attract biodiesel investment, with this being made possible because Ghana has a unique position of having low debt and perception of corruption [15]. In Tanzania, UKbased Sun Biofuels committed nearly 20 million dollars to J. curcas production and a biodiesel processing plant [14]. There are plans for expansion in other African countries as well, including Malawi, Burkina Faso, and Madagascar giving the increasing support from the private sector stakeholders, lower costs of production, and an ideal growing climate [16]. South Africa's biodiesel market is mainly characterized by several small- and medium-scale producers, while Zimbabwe's six million US-dollar biodiesel plant which was built to process Jatropha curcas, cotton seed, sunflower, and soya, among other feedstock, has not been fully operational due to political problems currently faced in the country [17]. The use of vegetable oil as a source of fuel for energy production has also been explored in some African countries such as Mali and Uganda. According to reports, South Africa, Angola, and Mozambique have the tendency to become the leading biofuels and carbon credit suppliers to world markets [18]. Currently, Angola has one of the largest nonforest agricultural lands in the world, and it is estimated that the country's biodiesel export potential is estimated at approximately six exajoules of bioenergy per year, the equivalent of 2.7 million barrels of oil per day (bpd) [19]. Angola and Mozambique have also joined forces with the Brazilian companies such as Petrobras (the national oil company), for example, in the development of soybean-based biodiesel allowing for more efficient development of the agriculture biofuels feedstock industry in both countries. Overall, many expect that the biofuels market in Africa will help the continent begin to realize its agricultural potential, bring real investment into irrigation technologies, and also lead to infrastructural growth and development. An attempt to create awareness of a shift to alternative fuel (biodiesel) was shown by a nongovernment, organization, "Journey to Forever", that travelled from Hong Kong to Southern Africa producing their own biodiesel along the way and teaching people from small villages how to make their own biodiesel to use in heaters, tractors, buses, automobiles, and other machines [20]. According to Mwakasonda [21], an energy expert with the United Nations (UN) Environment Program, worldwide investment in bioenergy reached twenty-one billion (USD) in 2008; "African countries are keen on capturing some of this market by transforming their expansive farmlands into the next oil fields." It should be also noted that, while by far the largest quantities of biodiesel fuels are still being produced and marketed within the European Union, the US and the Asian markets, a considerable rate of increase in biodiesel production is projected to occur in Africa with particular interest in South Africa; it is estimated that production might increase in folds by 2015 [22].

\section{Sustainability of Biofuels in Africa}

According to Sustainable Development Commission (SDC), the use of biofuels can lead to a reduction in greenhouse gases (GHGs), these reductions, however, require a series of careful measures to make this obtainable and have to be balanced against any environmental and social detriment amongst other factors [10]. There are several reasons for bio-fuels to be considered as relevant technologies by both developing and industrialized countries [2]; these reasons include the: source of foreign exchange saving activity especially for oil-deprived countries (development and use of locally produced renewable fuel and reduction of demand for imported petroleum), boosting of local agriculture productions, and additional markets and revenue to farmers leading consequently to the increase of rural folk's purchasing powers and quality of life, beneficial environmental impact through the usage of organic municipal solid waste materials to generating a higher-value endproduct, reduced level of carbon dioxide 
emitted by motor engines, and then preservation of the quality of the atmosphere. Ideally, biofuel alternatives should reduce the dependence on oil and contribute as much as possible to meet the GHG emissions target. However, it is also widely accepted that joint efforts from politicians, regulators, scientists, and consumers will be needed to support an independent oil/GHG-controlled scenario in the future. In South Africa, transport use contributes about $16 \%$ of the total greenhouse gas emissions, the greatest in Africa, and the transport sector accounts for about $26 \%$ of global $\mathrm{CO}_{2}$ emissions [23] of which roughly two thirds originate from the wealthiest $10 \%$ of the countries [24], and of this, diesel fuel contributes about $17 \%$ or $11,705,000$ tonnes of $\mathrm{CO}_{2}$ equivalent; 1,622,000 additional tonnes are released from diesel fuel used for electricity generation [25]. On top of greenhouse gas emissions is the vexing question of how little-or much-is left in order to reduce $\mathrm{CO}_{2}$ emissions from road transport. A significant modal shift onto a more environmentally benign source of energy is required [26] in which oils of vegetable and animal origin, unlike fossil fuels, have the potential to provide not only on a sustainable basis but could also be greenhouse gas neutral, or at the very least, emit substantially less greenhouse gases per unit energy. The need for a secure energy supply for transportation makes it essential to explore biofuels as alternatives to mineral oilbased fuels addressing and evaluating socioeconomic and environmental consequences originated in their implementation. Due to the environmental merits which also include availability from common biomass sources, representation of carbon dioxide cycle in combustion, possession of a considerable environmentally friendly potential, biodegradability, and contributions to sustainability, the share of biofuel in the automotive fuel market has been predicted to grow fast in the next decade according to reports by Monfort [27]. An exponential increase in the consumption of these biofuels has taken place in the last few years in the European Union (EU) according to reports by the IEA, 2007, and in order for biofuels to be viable alternatives to conventional fuels, it is recommended to provide net energy gain and to be environmentally beneficial, economically competitive and available in large quantities without reducing food supplies [28]. With a large landmass for farming, the Subsaharan Africa is increasingly being viewed as a region with a fairly high potential for biofuels production; bearing mainly energy security in mind, a number of countries have begun their own national biodiesel programs (Table 1) in which these countries still lag behind in biofuel potential. The growing interest in biofuels in many African countries can be explained by many factors. High crude oil prices, fluctuations in prices often due to geopolitical uncertainties, local and global environmental impacts of fossil fuels such as climate change, economic development, and employment are some of the drivers that are increasing the widespread interest in biofuels.

The underutilization of agricultural potentials in many African countries has also contributed to the increased push by domestic interests towards finding alternative outlets for their productive capacity. Most developed countries are also moving from voluntary legislation to obligatory legislation imposing market share of biofuels in the transport sector.
TABLE 1: Biofuels production potential of some African countries in megaliters [4].

\begin{tabular}{lcc}
\hline Country & Feedstock & Biofuels potential (ML) \\
\hline Kenya & Molasses & 413 \\
Ethiopia & Molasses & 80 \\
Nigeria & Sugarcane/Jatropha & 70 \\
South Africa & Sunflower & 215 \\
Zimbabwe & Jatropha & 100 \\
\hline
\end{tabular}

A mandatory blending legislation as well as internalization of biofuel external costs is required to reduce carbon dioxide emissions and improve energy security. To meet the European Union's aim of 5.75\% market share of biofuels in 2010 and about $8 \%$ by 2020 , countries will have to import feedstock from elsewhere, due to lack of sufficient arable land for energy crops and the well-established regulations safeguarding forests and governing land use. These EU biofuel targets have already triggered many investments in tropical biofuels [29]. The notion is that Africa has vast unused land areas that can be employed for biofuel production in order to generate export incomes, employment for rural people and smallholders, and profit for foreign investors. The rush towards biofuel production among foreign investors in Africa has created problems for governments to coordinate and guide such production. In many African countries, investors have started exploiting biofuel/biodiesel production without the existence of policies and regulatory framework for such productions. These could result in negative impacts on the environment such as deforestation, biodiversity loss, and land use problems. African countries are at the various stages of initiating commercial production of biofuels to capture the benefits of their value chain. This has led to large-scale mechanized feedstock/biofuel production, based on a model of industrial agriculture that uses large-scale pesticide and fertilizer input and measures productivity and effectiveness largely by the economic benefits with little consideration of social and environmental costs and benefits [30]. Sustainable development of biofuel industry in Africa can help kickstart investment in Africa's neglected agricultural sector, with positive spillover effects in terms of poverty reduction, food crop production and energy diversification, but governance and policy are required to ensure that these developments are carried out in a way that helps African countries achieve sustainable development. The concept of biofuels sustainability is extremely complex, and the views are diverse. To assess the sustainability of biofuels, the impact of the production, trade, and final conversion of the biofuel must be analyzed using an integrated approach and taking into account the three interlinked criteria of sustainable development such as social impacts (social well-being), environmental impacts (maintaining or improving environmental quality), and socioeconomic impacts (economic viability of biofuels production and associated welfare considerations) [31]. The fundamental issue with the production of biofuels is the use of landresources and the competition with food production. Therefore, agricultural practices need to be integrated; the Earth's natural resources, especially those of soil, water, 
plant and animal diversity, climate, and ecosystem services, are fundamental for the structure and function of agricultural systems in support of life on Earth. Historically, the developments in agriculture have concentrated on increasing productivity and effectively exploiting natural resources, but they have ignored complex interactions between agricultural activities, local ecosystems, and society. There are, therefore, several opportunities that can be realized through the integration of biofuel production with food production. There are also recent biofuels technological developments that can be applied to the usage of agricultural wastes for the production of biofuels [32].

\section{Biodiesel Production}

Biodiesel is defined as a fatty acid alkyl derived from the transesterification of vegetable oils or animal fats [33]. It is the product obtained when a vegetable oil or animal fat (triglyceride) reacts with an alcohol in the presence of a catalyst of which glycerol is a byproduct. Biodiesel can be prepared from a variety of sources including vegetable oils such as oilseeds, animal fats, waste oils, and greases [34]. In light of making biodiesel production more practical economically, the possibilities of converting its glycerol byproduct into value-added chemicals will provide more economically viable alternatives for the biodiesel industry. This tendency may lead to a decrease in biodiesel prices and could improve the glycerol market. Studies have shown that the glycerol commodity market is very limited and any increase in biodiesel production will cause a sharp decline of more than $50 \%$ of its current value. With the intended increased expansion of biodiesel productions and consequent potential decrease of glycerol prices, glycerol is expected to become a major platform chemical and has been recently identified as an important building block for future bio-refineries thus adding credit and value to the glycerol byproduct [35]. As a result, new opportunities and challenges exist for research and development in the biodiesel industry to propel the synergy needed for the transformation of glycerol into alue-added chemicals. In South Africa, the medium-scale production-biodiesel ranges between 200,000 litres to 300,000 liters monthly with an output of about 40,000 liters of glycerol monthly [36]. The price of glycerol obtained from waste oil feedstock was about 50 cents/liter, while the price of that obtained from refined oil was about 2 dollars per liter. The former is mainly used as an additive in animal feed requiring a maximum of $3 \%$ in total feed, also predominantly in local soap industries, and to produce antifreeze. The remaining is either stored away or disposed.

4.1. Value-Added Applications of Glycerol. Glycerol is a colorless, odorless, hygroscopic, and sweet-tasting viscous liquid, and because of its humectants properties, it is widely utilized in the cosmetic, pharmaceutical, and food industries; also has wide applications in lacquers, plastics, alkyl resins, tobacco, explosives, and cellulose processing. As reported by Yazdani and Gonzalez [37], the tremendous growth of the biodiesel industry has created a glycerol surplus that has resulted in a dramatic ten-fold decrease in crude glycerol prices; it is expected that the projected volume production of crude glycerol over the next five years will exceed the present commercial demand for purified glycerol, thus, new routes to convert crude glycerol, which is now considered a waste with an associated disposal cost, into higher-value products demand urgent attention.

The accumulation of crude glycerol resulting from biodiesel production propelled new ideas where some scientists tested the possibility of applying cheap crude glycerol as an animal feed ingredient in place of maize [38-41]. It has been found to be an attractive energy source for animal feed because of the similar energy value in comparison with corn and soybean meal; it, however, does pose a potential danger to the animals when the qualities of this biodiesel byproduct are not properly monitored [41]. The feedstock source and manufacturing process of biodiesel production are key factors in determining the composition of crude glycerol and its nutritional value [42]. It is, thus, necessary to analyze the physical, chemical, and nutritional properties of crude glycerol before including them into animal diet. A potential hazardous compound in crude glycerol is methanol with an acceptable level of methanol in crude glycerol to be used as a supplement in forage not exceeding $150 \mathrm{ppm}$ as methanol poisoning may cause central nervous system injury, weakness, headache, vomits, blindness, or Parkinsonian-like motor diseases in animals [43]. Lammers et al. [40] report that forage can be supplemented with $15 \%$ of glycerol without negative influence on egg production. Schieck et al. [44] stated that glycerol up to $9 \%$ can be used as a supplement in diet of lactating sows as an alternative energy source instead of maize. Previous research on finding new applications of glycerol includes its use as a low-cost feedstock for functional derivatives and additives for concrete chemicals and as a precursor of valued fine chemicals [45]. Low-value agricultural use involves mixing crude glycerol with manure for fertilizer or with feed for animals. Studies conducted by Donkin and Doane [38] indicate that glycerol as a valuable feed ingredient can be included as a macroingredient in diets for lactating dairy cows without any poisonous effect, presenting an alternative strategy for the formulation of diets when maize is not readily available. Glycerol can also be potentially transformed via bacteriologic processes into products that can be used for plastic production [46]. A promising and equally economically advantageous use is the conversion of glycerol into high-value products such as mono- and difatty acids [47]. Focusing on recent developments in the conversion of glycerol into value-added chemicals in future biorefineries, is the use of glycerol or its derivatives as a potential gasoline additive especially in the industrial synthesis of GTBE (glycerol tert-butyl ether) as shown in Figure 2. Methyl tertiary-butyl ether (MTBE) used as an antiknocking agent has been discredited due to its carcinogenity and its tendency to contaminate ground water [17]; GTBE, on the other hand, is considered safer than MTBE because it does not readily mix with water and, hence, reduces the likelihood of contaminating ground water in case of a spill [45]. Glycerol cannot be added directly to fuel because at high temperatures it polymerizes and, therefore, clogs the engine while partly 


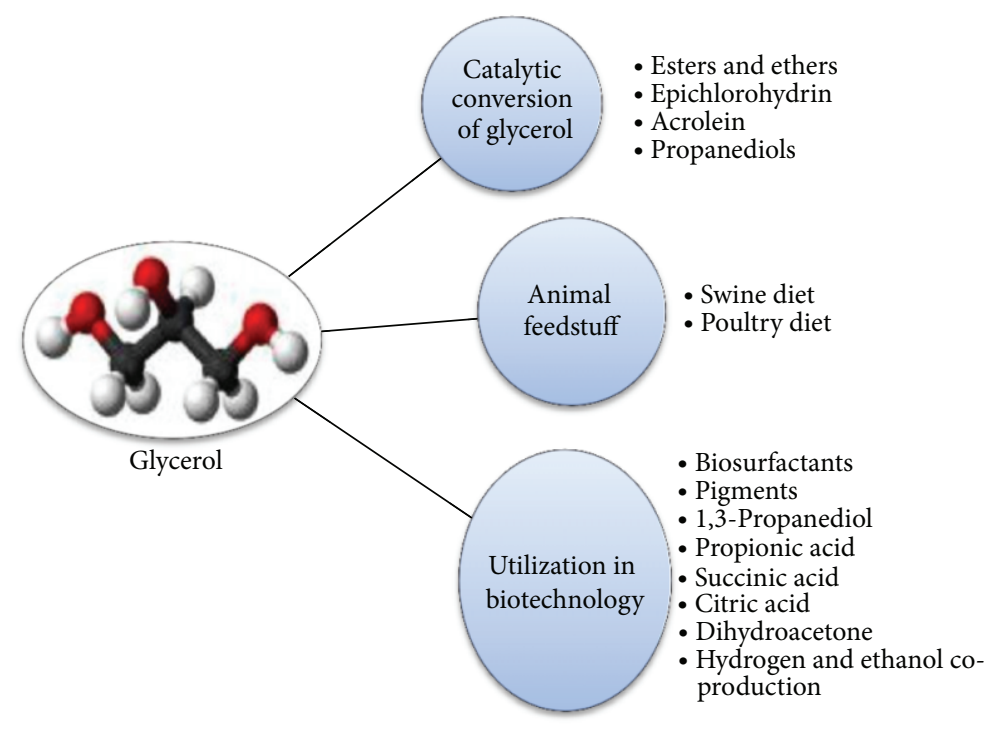

FIgURE 1: Value-added chemicals obtainable from glycerol.



FIGURE 2: Biodiesel formulation using GTBE.

getting oxidized to toxic acrolein. In this respect, glycerol tertiary-butyl ether (GTBE) poses as an excellent additive with a large potential for diesel and biodiesel reformulation. Various acetals and ketals can also be used as ignition accelerators and antiknock additives in combustion engines, proved to have lower levels of particle emissions, and can be added up to $10 \%$ volume of the fuels used, they can also be used as the base for surfactants [48]. According to a study [49], different oxygenated glycerol derivatives were synthesized from glycerol including acetals and ketals, and their emissions were evaluated with different kinds of vehicles and engines, and it was found out that a blend with $10 \%$ GTBE could be interesting to reduce particulate matter emissions by more than $20 \%$. Stating from an economical point of view, the manufacturing cost of GTBE is low among the different derivatives, and GTBE is a very promising additive, and the benefits of blending GTBE in diesel fuel not limited to its performance for reducing particulate matter (PM) emissions; it also plays a part in the reduction of $\mathrm{CO}_{2}$ emissions. Various tests carried out by Jaecker-Voirol et al. [49] deduce that the use of this reformulation does not present any technical disadvantage; therefore, GTBE could be considered as an excellent additive with a large potential for diesel and biodiesel reformulation. The use of GTBE in Africa would have significant health benefits in replacing lead as an octane enhancer in most African countries where leaded fuel is still widely used; of a total of 49 countries in the Subsaharan Africa, 22 countries only use leaded fuel; only 14 use a dual system, while 13 use the unleaded fuel [50]. The ultimate decision, however, to use GTBE in biodiesel formulation would be controlled by economic criteria and the willingness on the part of industry. In other perspectives, the use of anaerobic fermentation to convert abundant and low-priced glycerol streams generated in the production of biodiesel into higher-value products also presents a promising route to attain economic viability in the biofuels industry. The use of crude glycerol has also been verified as an ideal carbon source for the fermentation processes by microorganisms [51]. Clearly, the development of processes to convert crude glycerol into higher-value products as shown in Figure 1 is both an urgent need and a "target of opportunity" for the development of biorefineries. Such technologies could be readily integrated into existing biodiesel facilities, thus establishing true biorefineries and revolutionizing the biodiesel industry by dramatically improving its economics [47]. In terms of green chemistry, the incorporation of glycerol into biofuel can improve the efficiency of the process without substantial modifications of its physicochemical properties with a novel biofuel patent denoted as Ecodiesel-100 obtained via 1, 3-selective partial ethanolysis of triglycerides with a lipase. Studies conducted reveal that the Ecodiesel-100 incorporates glycerol in its mono-phasic homogeneous mixtures requiring no additional separation steps as compared with conventional biodiesel production while proffering the advantage of the elimination of byproducts during the preparation process [52]. Recent studies have also demonstrated that the presence of mono triglyceride adds value to the biofuel by improving the lubricity on the engine and the atom efficiency is also improved as the total number of atoms involved in the reaction is part of the final mixture. The possibility of using crude glycerol byproduct from the biodiesel industry as 
a carbon source for microalgae that produces omega-3 fatty acids has also been established, adding to the fact that impurities in crude glycerol may actually be beneficial to algal growth [53].

\section{Conclusion}

Biofuels have a crucial role to play in fulfilling the longterm goal of limiting the growth of GHG emissions and the transition of the current petroleum-based society towards a more sustainable one. Biodiesel production could offer the developing African countries potential economic, ecological, social, and security benefits while pursuing and advocating the implementation of biodiesel use on the continent. Surely, there is a large room for improvement in biodiesel production; strong political will on the part of governments will go a long way in achieving a prospect of self-reliance with respect to energy supplies at national and local levels. However, the cost of biodiesel production is quite high, and it exceeds prices of traditional; fuels, thus the inevitability of making biodiesel production more practical economically via the possibilities of converting its glycerol byproduct into value-added chemicals will provide more economically viable alternatives for the biodiesel industry. The utilization of crude glycerol into higher-value products would greatly increase the net energy, sustainability and profitability of the biodiesel industry overall. In summary, the pace of biodiesel sustainability can be met on the African continent if all hands of producers, research, and development in educational institutions and governments (politicians and political structures) are on deck.

\section{Acknowledgment}

The authors wish to acknowledge the contributions of late Dr. Bamikole Amigun to this paper.

\section{References}

[1] W. Tsai, "Energy sustainability from analysis of sustainable development indicators: a case study in Taiwan," Renewable and Sustainable Energy Reviews, vol. 14, no. 7, pp. 2131-2138, 2010.

[2] B. Amigun, F. Müller-Langer, and H. von Blottnitz, "Predicting the costs of biodiesel production in Africa: learning from Germany," Energy for Sustainable Development, vol. 12, no. 1, pp. 5-21, 2008.

[3] K. J. Singh and S. S. Sooch, "Comparative study of economics of different models of family size biogas plants for state of Punjab, India," Energy Conversion and Management, vol. 45, no. 9-10, pp. 1329-1341, 2004.

[4] B. Amigun, J. K. Musango, and W. Stafford, "Biofuels and sustainability in Africa," Renewable and Sustainable Energy Reviews, vol. 15, no. 2, pp. 1360-1372, 2011.

[5] A. I. Eleri and E. O. Eleri, "Prospects for Africa-Rethinking Biomass Energy in Sub-Sahara Africa. Prospects for AfricaEurope Policies," The VENRO -Project on the Africa -Eu Partnership, Bonn, Germany, 2009.

[6] W. K. Biswas, P. Bryce, and M. Diesendorf, "Model for empowering rural poor through renewable energy technologies in
Bangladesh," Environmental Science and Policy, vol. 4, no. 6, pp. 333-344, 2001.

[7] S. Fernando, S. Adhikari, K. Kota, and R. Bandi, "Glycerol based automotive fuels from future biorefineries," Fuel, vol. 86, no. 1718, pp. 2806-2809, 2007.

[8] R. S. Karinen and A. O. I. Krause, "New biocomponents from glycerol," Applied Catalysis A, vol. 306, pp. 128-133, 2006.

[9] T. Willke and K.-D. Vorlop, "Industrial bioconversion of renewable resources as an alternative to conventional chemistry," Applied Microbiology and Biotechnology, vol. 66, no. 2, pp. 131142, 2004.

[10] O. Davidson and M. Chenene, Sustainable Energy in SubSaharan Africa, ICSU Regional Office For Africa Science Plan Report Pretoria, International Council for Science, Johannesburg, South Africa, 2007.

[11] R. Blinca, A. Zidansěka, and I. Šlausc, "Sustainable development and global security," Energy, vol. 32, pp. 883-890, 2007.

[12] V. Schalkwy, http://www.allafrica.com/, 2012.

[13] M. Balat and H. Balat, "A critical review of bio-diesel as a vehicular fuel," Energy Conversion and Management, vol. 49, no. 10, pp. 2727-2741, 2008.

[14] W. Thurmond, "Global Biodiesel Market trends, Outlook and opportunities (pdf)," http://www.unece.isu.edu/biofuels/documents/2010Aug/b10_16.pdf, 2012.

[15] M. Johnston and T. Holloway, "A global comparison of national biodiesel production potentials," Environmental Science and Technology, vol. 41, no. 23, pp. 7967-7973, 2007.

[16] W. Thurmond, "Biodiesel 2020: A global Market survey, Volume two," Emerging markets, http://www.emerging-markets.com/, 2012.

[17] B. Amigun, R. Sigamoney, and H. von Blottnitz, "Commercialisation of biofuel industry in Africa: a review," Renewable and Sustainable Energy Reviews, vol. 12, no. 3, pp. 690-711, 2008.

[18] "Africa's biofuel boom: Mozambique," http://www.iol.co.za/ index.php/, http://www.worldwatch.org/node/5450, 2012.

[19] A. A. Kiss, A. C. Dimian, and G. Rothenberg, "Solid acid catalysts for biodiesel production-towards sustainable energy," Advanced Synthesis and Catalysis, vol. 348, no. 1-2, pp. 75-81, 2006.

[20] "Journey to Forever. National standards for biodiesel," http:// www.journeytoforever.org/biodiesel_yield2.html\#biodstds, 2006.

[21] S. Mwakasonda, "Moving toward sustainable biofuel programs in Africa," in Proceedings of the 1st High-Level Biofuel Seminar in Africa, Addis Ababa, Ethiopia, 2007.

[22] M. Canakci and J. Van Gerpen, "A pilot plant to produce biodiesel from high free fatty acid feedstocks," Transactions of the American Society of Agricultural Engineers, vol. 46, no. 4, pp. 945-954, 2003.

[23] L. Chapman, "Transport and climate change: a review," Journal of Transport Geography, vol. 15, pp. 354-367, 2007.

[24] M. Lenzen, C. Dey, and C. Hamilton, "Climate change," in Handbook of Transport and the Environment, pp. 37-60, Elsevier, Amsterdam, The Netherlands, 4th edition, 2003.

[25] M. Nolte, Commercial biodiesel production in South Africa: a preliminary economic feasibility study [M.S. thesis], Department of Chemical Engineering, University of Stellenbosch, Stellenbosch, South Africa, 2007.

[26] B. J. Waterson, B. Rajbhandari, and N. B. Hounsell, "Simulating the impacts of strong bus priority measures," Journal of Transportation Engineering, vol. 129, no. 6, pp. 642-647, 2003. 
[27] M. C. Monfort, "Global trends in seafood and sustainability: market movements and trends," in Proceedings of the Seafood Choice Alliance Conference, Barcelona, Spain, 2008.

[28] IEA, "World energy outlook 2007," International Energy Agency Paris http://www.mybiodiesel.com/biodiesel-history.php, 2007.

[29] G. Sorda, M. Banse, and C. Kemfert, "An overview of biofuel policies across the world," Energy Policy, vol. 38, no. 11, pp. 69776988, 2010.

[30] H. S. Dillon, T. Laan, and H. S. Dillon, "Biofuels-at what cost? Government support for ethanol biodiesel in Indonesia. The Global Studies Initiative," Part of the International Institute for Sustainable Development, 2008.

[31] E. Smeets, M. Junginger, A. Faaij, A. Walter, P. Dolzan, and W. Turkenburg, "The sustainability of Brazilian ethanol-An assessment of the possibilities of certified production," Biomass and Bioenergy, vol. 32, no. 8, pp. 781-813, 2008.

[32] S. R. Gliessman, Agroecology: Ecological Processes in Sustainable Agriculture, Ann Arbor Press, Michigan. Mich, USA, 1998.

[33] M. S. Friedrich, A worldwide review of the commercial production of biodiesel-a Technological, economic and ecological investigation based on case studies [M.S. thesis], Institute fur Technologie und Nachhaltiges produkt management, Vienna, Austria, 2004.

[34] D. Dermirbas and S. Karslıglu, "Biodiesel production facilities from vegtable oils and animal fats," Energy Source, vol. 29, pp. 33-141, 2007.

[35] K. S. Tyson, J. Bozell, R. Wallace, E. Petersen, and L. Moens, "Biomass oil analysis," Research Needs and Recommendations NREL/TP-510-34796, 2004.

[36] O. Nieuwoudt, "Glycerol inventory in South Africa," Private Communication, 2011.

[37] S. S. Yazdani and R. Gonzalez, "Anaerobic fermentation of glycerol: a path to economic viability for the biofuels industry," Current Opinion in Biotechnology, vol. 18, no. 3, pp. 213-219, 2007.

[38] S. S. Donkin and P. H. Doane, "Glycerol from biodiesel production: the new corn for dairy cattle," Nutrition Research, vol. 37, 2008.

[39] S. Cerrate, F. Yan, Z. Wang, C. Coto, P. Sacakli, and P. W. Waldroup, "Evaluation of glycerine from biodiesel production as a feed ingredient for broilers," International Journal of Poultry Science, vol. 5, no. 11, pp. 1001-1007, 2006.

[40] P. J. Lammers, B. J. Kerr, T. E. Weber et al., "Digestible and metabolizable energy of crude glycerol for growing pigs," Journal of Animal Science, vol. 86, no. 3, pp. 602-608, 2008.

[41] W. A. Dozier, B. J. Kerr, A. Corzo, M. T. Kidd, T. E. Weber, and K. Bregendahl, "Apparent metabolizable energy of glycerin for broiler chickens," Poultry Science, vol. 87, pp. 317-322, 2008.

[42] C. F. Hansen, A. Hernandez, B. P. Mullan et al., "A chemical analysis of samples of crude glycerol from the production of biodiesel in Australia, and the effects of feeding crude glycerol to growing-finishing pigs on performance, plasma metabolites and meat quality at slaughter," Animal Production Science, vol. 49, no. 2, pp. 154-161, 2009.

[43] D. C. Dorman, J. A. Dye, M. P. Nassise, J. Ekuta, B. Bolon, and M. A. Medinsky, "Acute methanol toxicity in minipigs," Fundamental and Applied Toxicology, vol. 20, no. 3, pp. 341-347, 1993.

[44] S. J. Schieck, B. J. Kerr, S. K. Baidoo, G. C. Shurson, and L. J. Johnston, "Use of crude glycerol, a biodiesel coproduct, in diets for lactating sows," Journal of Animal Science, vol. 88, no. 8, pp. 2648-2656, 2010.
[45] A. Behr, J. Eilting, K. Irawadi, J. Leschinski, and F. Lindner, "Improved utilisation of renewable resources: new important derivatives of glycerol," Green Chemistry, vol. 10, no. 1, pp. 13-30, 2008.

[46] B. A. Hunt, "Production of Ethers of Glycerol from Crude Glycerol-The By-Product of Biodiesel Production," http://digitalcommons.unl.edu/chemeng, 1998.

[47] C. Zhou, J. N. Beltramini, Y. Fan, and G. Q. Lu, "Chemoselective catalytic conversion of glycerol as a biorenewable source to valuable commodity chemicals," Chemical Society Reviews, vol. 37, no. 3, pp. 527-549, 2008.

[48] A. Piasecki, A. Sokolowski, and B. Burczyket, "Fatty Acid condensates," Journal of the American Oil Chemists' Society, vol. 74, pp. 33-37, 1997.

[49] A. Jaecker-Voirol, I. Durand, G. Hillion, B. Delfort, and X. Montagne, "Glycerin for new biodiesel formulation," Oil and Gas Science and Technology, vol. 63, no. 4, pp. 395-404, 2008.

[50] V. Thomas and A. Kwong, "Ethanol as a lead replacement: phasing out leaded gasoline in Africa," Energy Policy, vol. 29, no. 13, pp. 1133-1143, 2001.

[51] N. Özbay, N. Oktar, and N. A. Tapan, "Esterification of free fatty acids in waste cooking oils (WCO): role of ion-exchange resins," Fuel, vol. 87, no. 10-11, pp. 1789-1798, 2008.

[52] R. Luque, L. Herrero-Davila, J. M. Campelo et al., "Biofuels: a technological perspective," Energy and Environmental Science, vol. 1, no. 5, pp. 542-564, 2008.

[53] Z. Wen, "Researcher converts biodiesel-waste glycerol into omega-3 fatty acids," http://www.phys.org/news138543542 .html, 2012. 


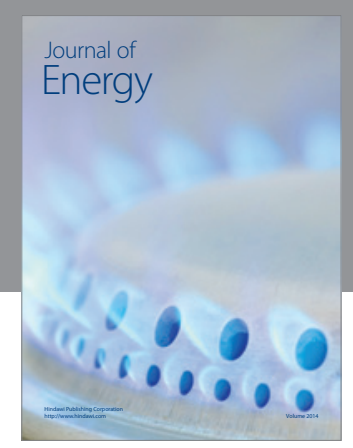

Journal of

Industrial Engineering
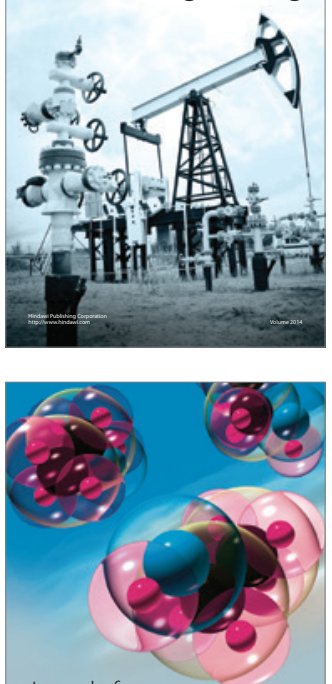

Fuels


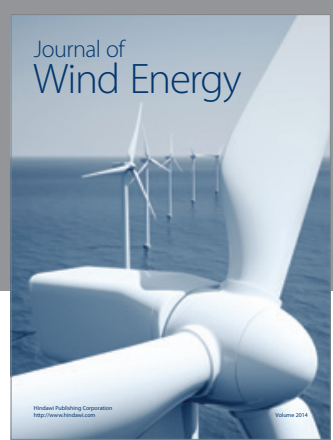

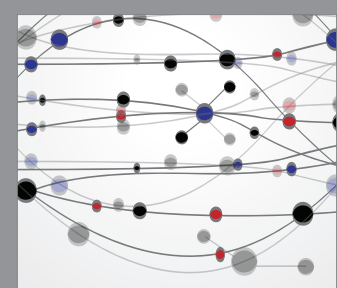

The Scientific World Journal

Submit your manuscripts at http://www.hindawi.com

Journal of

Structures
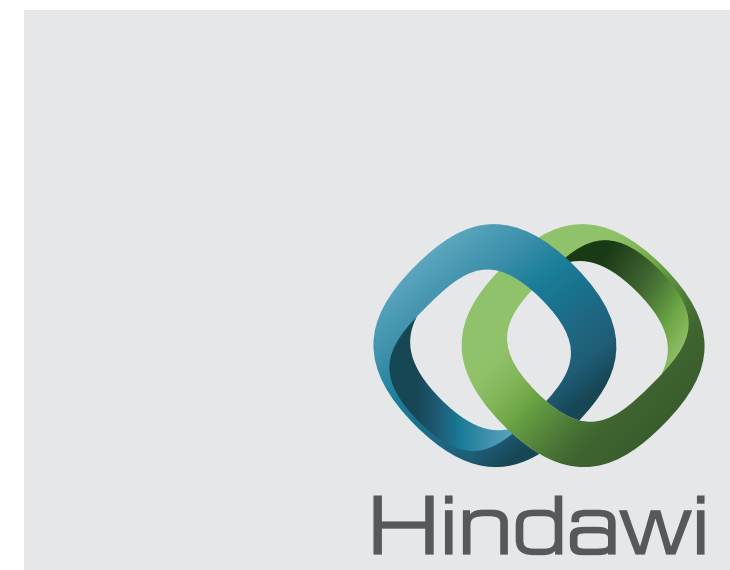

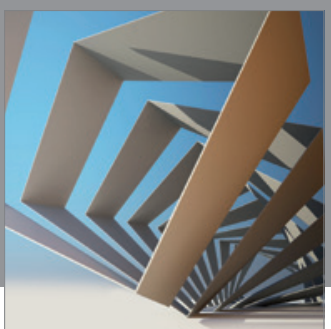

Rotating

Machinery
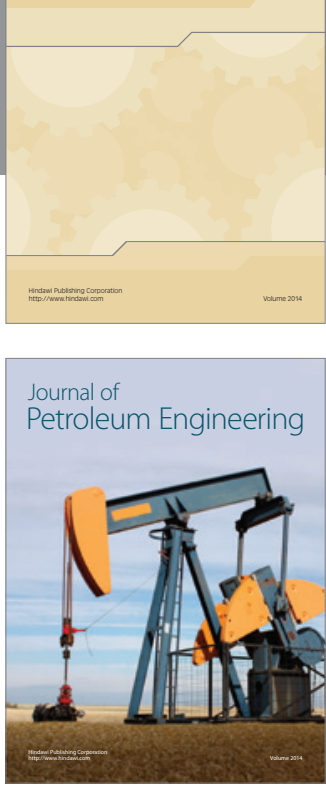

Journal of

Solar Energy
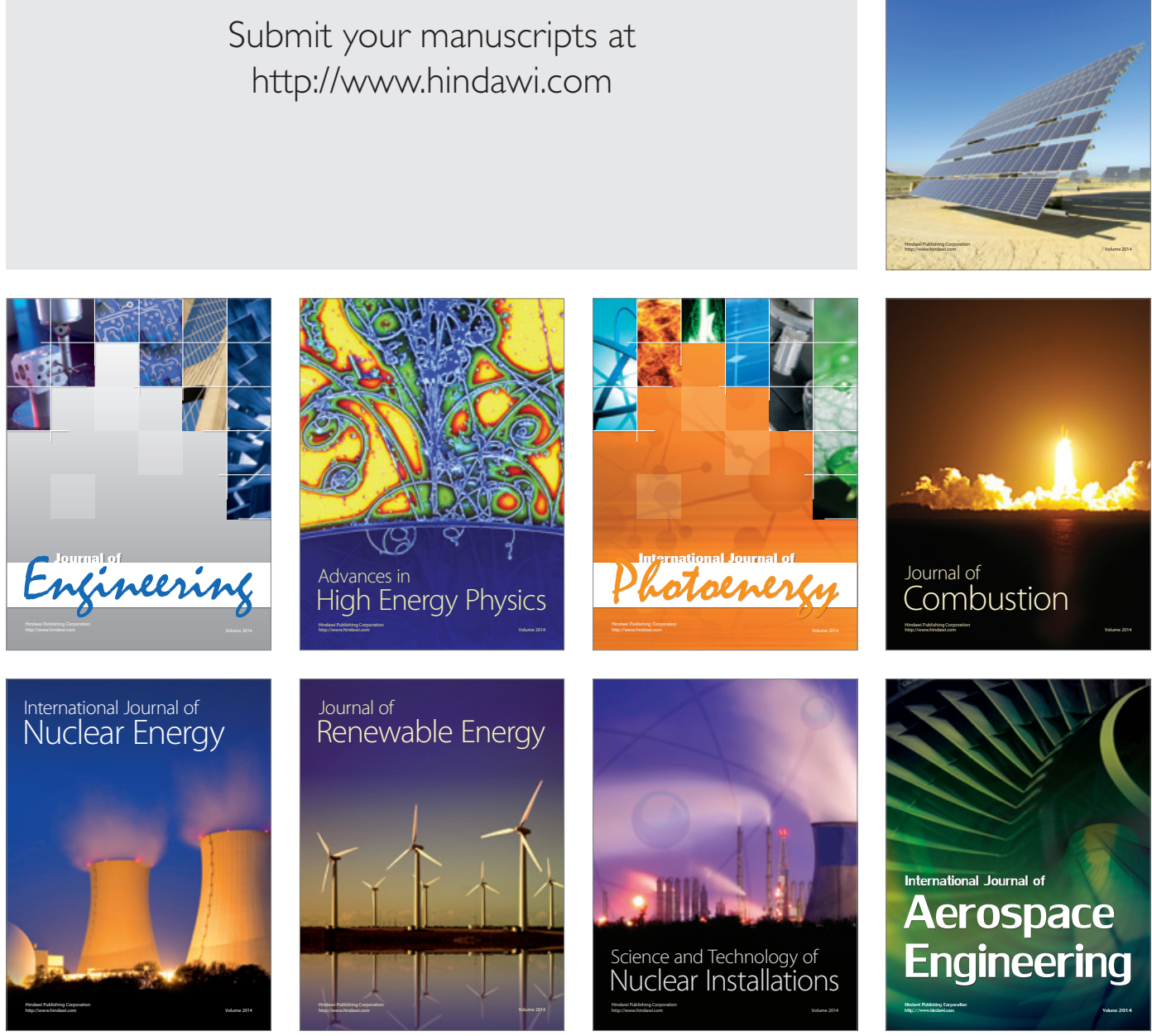